\title{
Production and Reproduction of Egg- and Meat- type Quails Reared in Different Group Sizes
}

\section{-Author(s)}

Santos TC $1 *$

Murakami $\mathrm{AE}^{1}$

Fanhani JC

Oliveira CAL

1 Departamento de Zootecnia, Universidade Estadual de Maringá.

2 Undergraduate student of Departamento de Zootecnia, Universidade Estadual de Maringá.

\section{Mail Adress}

Tatiana Carlesso dos Santos Departamento de Zootecnia Universidade Estadual de Maringá Av. Colombo, 5790

87.020-900, Maringá, PR, Brasil.

Phone +55 4430114919

E-mai: tcsantos@uem.br

\section{-Keyw ords}

Fertility, hatchability, quail, reproduction, vitelline membrane.

\section{-Acknow ledgements}

The authors thank CNPq for the grant.

\section{ABSTRACT}

Egg- and meat-type quails were reared in groups of different sizes with a fixed female-to-male ratio of 2 to 1 and an area of $158 \mathrm{~cm}^{2}$ per bird. The aim was to investigate the influence of group size on quail production and reproductive variables. To this end, 360 quails (180 meat and 180 egg-type quails) were assigned in a completely randomized experimental design to one of three treatments with ten replicates each. The treatments consisted of groups with nine, six, or three quails per cage. Birds were observed for three cycles of 14 days. Daily feed intake and feed conversion ratio were influenced $(p<0.05)$ by group size in both types of quails. Quail type influenced $(p<0.05)$ daily feed intake, feed conversion, and egg weight due to the typical differences between meat and egg-type birds. Despite the observed differences in production parameters, the mean values observed were typical of meat- and egg-type quails. The number of hydrolysis points (holes) per $\mathrm{mm}^{2}$ on the vitelline membrane on the germinal disc area was higher in meat quails $(2.89 \pm 0.21)$ than in egg quails $(2.15 \pm$ $0.13)$. This parameter was not influenced by the number of birds per cage, which suggests that the number of males inside the cage did not modify the spermatozoa pool inside the female oviduct. We concluded that a ratio of two females per male in cages with three, six, and nine birds/cage is recommended, as no deleterious effect on quail reproduction was observed.

\section{INTRODUCTION}

Quail rearing for meat and egg production in Brazil has become an economically viable activity and has increasingly developed. From the technical and economic viewpoints, quail rearing is attractive due to their rapid growth and early onset of lay, high reproduction rates, and low feed intake (M urakami \& Ariki, 1998; Albino \& Barreto, 2003).

The development of quail culture has led farmers to rear both meatand egg-type quail breeders, which has demanded studies on the reproductive management of this species. General data on the ideal male-to-female ratios, hatching egg storage time, correlation between egg weight and fertility rate, hatchability (Bacon \& Nestor, 1975; Narahari et al., 1988; Kobayashi et al., 1994; Adkins-Regan, 1995; Petek et al., 2003; Hassan et al., 2003), and fertility duration (Sittman \& Abplanalp, 1965; Reddish et al., 1996) have been described for egg-type quails.

The most studied aspect of quail production is nutrition, particularly of Japanese egg-type quails (Garcia et al., 2000; Ribeiro et al., 2003; Murakami et al., 2006; Araujo et al., 2007; Murakami et al., 2007). On the hand, there are few studies on the egg production potential of European meat-type quails (M ori et al., 2005; Barreto et al., 2007b), and therefore, on their reproduction capacity. 
The reproduction strategies of male birds usually involve the rapid production, maturation, and transport of spermatozoa through the genital organs, which is associated with the sperm storage capacity in the genital tract limited to merely one day (Clulow \& Jones, 1982). Experiments with breeding quails have demonstrated that the number of fertile eggs drops sharply when males are removed from the group (Sittman \& Abplanalp, 1965). Although spermatozoa can survive in the female genital tract for more than 14 days, they are able to fertilize only $45 \%$ of the eggs eight days after the removal of the males (Reddish et al., 1996).

Studies on the number of holes produced by spermatozoa through the inner perivitelline layer (IPVL holes) or outer perivitelline layer (OPVL sperm) as a function of time allow inferring the fertility status of eggs laid and yet to be laid by a given female on the subsequent days while it continues to lay fertile eggs (Wishart \& Staines, 1999; Hazary, 2000). Fertile eggs laid on consecutive days may result from a single mating or a sperm pool stored in the female genital tract (Bramwell \& M cDaniel, 1986). For these reasons, this method is adequate to estimate the breeding potential of breeder quails and to correlate it to the number of males and females per cage.

The development of the reproductive organs and breeding efficiency are directly influenced by the number of birds per cage during different rearing phases. Cage type and number of birds per cage were evaluated seeking to reduce quails production costs (Faitarone et al., 2005; Lopes et al., 2006). The number of birds per cage in a given group may influence production and reproduction factors, particularly in breeders, due to the presence of different males in the same cage and the competition between males for females, sexual activity, social interactions, and constant competition for space and feed. Therefore, we studied the influence of the number of males and females of egg- and meat-type quail breeders per cage on reproduction and production variables using fixed male-to-female ratios and bird per cage numbers.

\section{MATERIALS AND METHODS}

The experiment was carried out from January to March 2009 at the poultry sector of the Experimental Farm of the Universidade Estadual de Maringá using 17-week-old egg- and meat-type quails for 45 days in a 15-day cycle evaluation. A total of 360 quails, 180 meat-type quails (European) and 180 egg-type quails
(Japanese), were assigned to three experimental groups consisting of three, six, or nine birds/cage, with ten replicates per group, at a fixed female-to-male ratio of two:one in a completely randomized experimental design.

Egg and meat quails weighed 140 to $170 \mathrm{~g}$ and 240 to $270 \mathrm{~g}$, respectively. Groups of three, six, and nine quails were housed in stacked, galvanized-wire cages measuring $19 \times 25 \times 14 \mathrm{~cm} ; 38 \times 25 \times 14 \mathrm{~cm}$, and $57 \times 25 \times 14 \mathrm{~cm}$ (length $x$ width $x$ height), respectively, maintaining an area of $6.3 \mathrm{~cm}$ of feeder/bird. The cage area per bird was maintained at $158.3 \mathrm{~cm}^{2} / \mathrm{bird}$ in all treatments, both for egg and meat quails.

Birds had free access to water and feed in trough feeders and nipple drinkers, and were submitted to $17 \mathrm{~h}$ of natural and artificial light. Feed was based on corn and soybean meal, containing 20\% CP and 2,900 $\mathrm{kcal} \mathrm{ME} / \mathrm{kg}$, and other nutrients according to the NRC (1994) and Rostagno et al. (2005).

The following production parameters were evaluated: feed intake ( $\mathrm{g} / \mathrm{bird} /$ day), percentage of lay (\% /bird/day), egg weight (g), and feed conversion ratio per egg mass and per dozen eggs $(\mathrm{kg}$ feed $/ \mathrm{kg}$ eggs and $\mathrm{kg}$ feed/dozen eggs). Egg production per replicate was monitored daily to determine percentage of lay and total number of eggs laid in each cycle. During the last three days of each cycle, eggs were weighed, and on the 15th day of the cycle, feed intake and feed conversion ratio were evaluated.

Fertility (\% total eggs - infertile eggs) and hatchability (\% hatched eggs relative to fertile eggs) were determined by collecting the eggs of each replicate during the second cycle for four consecutive days. Eggs were kept refrigerated $\left(20^{\circ} \mathrm{C}\right)$ and placed in an incubator with controlled moisture and temperature. Additional fertility data were obtained from eggs collected for two consecutive days of each cycle. These eggs were broken and classified according to the macroscopic morphology of the germinal disc as fertile or infertile (Kosin, 1945).

In order to determine the number of holes made by spermatozoa in the inner perivitelline membrane (IPVL holes), 50 eggs per treatment were analyzed. Fragments measuring $1 \times 1 \mathrm{~cm}$ of the perivitelline membrane on the germinal disc and opposing pole of fertile eggs were collected. Fragments were washed in $1 \% \mathrm{NaCl}$, placed onto glass slides, stained with Schiff's periodic acid, slip-covered (Bramwell et al., 1995), and examined under a light microscope at $20 \mathrm{X}$ magnification. The number of IPVL holes was counted in 10 areas per region (germinal disc and opposing pole), totaling $3.3 \mathrm{~mm}^{2}$ per region. 
The evaluated variables were submitted to analysis of variance using Statistical Analysis System software package (SAS, 2000). M eans of the treatments (birds per cage) and of quail type (meat or egg) and their possible interactions were tested using general linear models and Tukey's test at 5\% probability.

\section{RESULTS AND DISCUSSION}

The performance and reproduction results are presented in Tables 1 and 2. Performance parameters, such as feed intake, feed conversion ratio ( $\mathrm{kg}$ feed/ $\mathrm{kg}$ egg and $\mathrm{kg}$ feed/dozen eggs) were different $(p<0.05)$ when analyzed as a function of the number of birds per cage. Quail type also influenced feed intake, feed conversion ratio $(\mathrm{kg} / \mathrm{dz})$, and egg weight. As to reproductive parameters, the number of IPVL holes on the germinal disc area was influenced by quail type, and fertility was affected by the interaction between the number of birds per cage and quail type.
Feed intake was higher in meat-type quails than in egg-type quails due to their higher body weight (240$270 \mathrm{~g}$ ) as compared to that of egg-type quails (140$170 \mathrm{~g})$. In both quail types, groups of three birds/cage consumed the most feed. However, quails in groups of six or nine birds/cage were not different in terms of feed intake. Feed conversion ratio $(\mathrm{kg} / \mathrm{kg}$ and $\mathrm{kg} /$ $\mathrm{dz}$ ) was better in the group of nine birds/cage for both quail types. Egg-type quails presented the best feed conversion ratio in $\mathrm{kg} / \mathrm{dz}$.

In average, meat-type quails consumed $30.04 \mathrm{~g}$ of feed and had mean conversion ratios of $2.49 \mathrm{~kg} / \mathrm{g}$ and $0.39 \mathrm{~kg} / \mathrm{dz}$, in agreement with previous studies reporting average feed intakes ranging from 30 to 33g (Albino \& Barreto, 2003; Barreto et al., 2007a). However, Mori et al. (2005) observed averages of $37 \mathrm{~g}$ of feed intake/bird/day and feed conversion ratio of about $3.86 \mathrm{~kg} / \mathrm{kg}$ and $0.59 \mathrm{~kg} / \mathrm{dz}$ in different genetic groups of meat-type quail.

The evaluated egg-type quails also presented daily

Table 1 - M ean and standard errors of feed intake, feed conversion per egg mass, feed conversion per dozen eggs, percentage of lay, and egg weight of meat- and egg-type quail breeders reared at different numbers of birds per cage.

\begin{tabular}{|c|c|c|c|c|c|}
\hline & $\begin{array}{l}\text { Feed intake } \\
\text { (g/bird/day) }\end{array}$ & $\begin{array}{l}\text { Feed conversion } \\
(\mathbf{k g} / \mathbf{k g})\end{array}$ & $\begin{array}{l}\text { Feed conversion } \\
\text { (kg/dozen) }\end{array}$ & $\begin{array}{l}\text { Lay } \\
(\%)\end{array}$ & $\begin{array}{l}\text { Egg w eight } \\
\text { (g) }\end{array}$ \\
\hline \multicolumn{6}{|c|}{ Birds per cage } \\
\hline 3 & $28.74 \pm 0.87 a$ & $2.55 \pm 0.05 a$ & $0.38 \pm 0.01 a$ & $92.32 \pm 1.71$ & $12.30 \pm 0.23$ \\
\hline 6 & $26.94 \pm 0.89 b$ & $2.49 \pm 0.05 a$ & $0.36 \pm 0.01 a$ & $90.18 \pm 1.66$ & $12.07 \pm 0.26$ \\
\hline 9 & $25.86 \pm 0.77 b$ & $2.31 \pm 0.04 b$ & $0.34 \pm 0.01 b$ & $91.61 \pm 1.38$ & $12.23 \pm 0.26$ \\
\hline \multicolumn{6}{|l|}{ Quail type } \\
\hline M eat & $30.04 \pm 0.45 a$ & $2.50 \pm 0.03$ & $0.39 \pm 0.01 a$ & $91.60 \pm 1.00$ & $13.19 \pm 0.10 a$ \\
\hline$\overline{E g g}$ & $24.16 \pm 0.47 b$ & $2.40 \pm 0.05$ & $0.32 \pm 0.01 b$ & $91.14 \pm 1.54$ & $11.22 \pm 0.07 b$ \\
\hline Mean & $27.15 \pm 0.50$ & $2.45 \pm 0.03$ & $0.36 \pm 0.006$ & $91.37 \pm 0.91$ & $12.2 \pm 0.14$ \\
\hline CV (\%) & 8.36 & 8.55 & 8.60 & 7.79 & 3.93 \\
\hline Interaction & NS & NS & NS & NS & NS \\
\hline
\end{tabular}

Table 2 - M eans and standard errors of hatching, fertility, IPVL holes over the germinal disc (disc) and on the opposite pole (opposite) of meat- and egg-type quail breeders reared at different numbers of birds per cage.

\begin{tabular}{|c|c|c|c|c|}
\hline & Hatching (\%) & Fertility (\%) & IPVL holes $/ \mathrm{mm}^{2}$ disc & IPVL holes/mm² opposite \\
\hline \multicolumn{5}{|c|}{ Birds per cage } \\
\hline 3 & $90.53 \pm 2.66$ & $98.27 \pm 0.75$ & $2.55 \pm 0.27$ & $0.69 \pm 0.12$ \\
\hline 6 & $83.19 \pm 2.38$ & $98.08 \pm 0.61$ & $2.51 \pm 0.16$ & $0.79 \pm 0.13$ \\
\hline 9 & $85.88 \pm 2.19$ & $98.10 \pm 0.36$ & $2.50 \pm 0.26$ & $0.75 \pm 0.10$ \\
\hline \multicolumn{5}{|l|}{ Quail type } \\
\hline Meat & $85.34 \pm 1.95$ & $98.02 \pm 0.47$ & $2.89 \pm 0.21 a$ & $0.84 \pm 0.11$ \\
\hline Egg & $87.57 \pm 2.08$ & $98.29 \pm 0.48$ & $2.15 \pm 0.14 b$ & $0.63 \pm 0.07$ \\
\hline Mean & $86.46 \pm 1.42$ & $98.15 \pm 0.33$ & $2.52 \pm 0.13$ & $0.74 \pm 0.06$ \\
\hline CV $(\%)$ & 12.39 & 2.40 & 39.50 & 70.18 \\
\hline Interaction & NS & $P=0.0028$ & NS & NS \\
\hline
\end{tabular}


feed intakes and feed conversion ratios consistent to those found in literature (Barreto et al., 2007b; M oura et al., 2008; M urakami et al., 2006). Lopes et al. (2006) found no effect of different numbers of birds per cage and energy levels on these performance parameters of egg-type quails ( $p>0.05)$. The bird density of $151.8 \mathrm{~cm}^{2} /$ bird reported in that study was lower than that used in the present study, and did not influence percentage of lay $(\%)$, feed intake, or egg weight.

Quail average egg weight was not affected ( $p>$ 0.05 ) by the number of birds per cage. As expected, average egg weight was affected by quail type. M eatquail eggs weighed $13.18 \mathrm{~g}$ in average, similarly to that reported by Mori et al. (2005). whereas the eggs of egg-type quails weighed $11.22 \mathrm{~g}$ in average, which value is consistent with those obtained by Murakami \& Ariki (1998), Garcial et al. (2000), Murakami et al. (2006, 2008), Kadam et al. (2006), and Oliveira et al. (2007).

Quail groups with nine birds may suffer social stress due to the presence of three males in the same cage and their competition for females. However, even in these groups, no difference in egg production ( $p>0.05$ ) was observed. Average percentage of lay during the studied period was, $91.37 \%$, and was not influenced by quail type or number of birds per cage. Values ranging from 85 to $90 \%$ (Murakami \& Ariki, 1998) were reported for egg-type quails and from 93 to $95 \%$ for meat-type quails (Albino \& Barreto, 2003). Barreto et al. (2007a) found an average percentage of lay of $90.64 \%$ for meat-type quails. However, Faitarone et al. (2005) observed that the percentage of lay was reduced as the number of birds per cage and dietary energy level increased, obtaining $79.23 \%$ lay at a bird density of $151 \mathrm{~cm}^{2} /$ bird (21 meat-type quails).

The reproductive performance data are presented in Table 2. Fertility was influenced by the interaction ( $p=0.0028$ ) between quail type and birds per cage, particularly in cages with six birds. The other groups were not influenced by the treatments ( $p>0.05)$ (Table 3).

Table 3 - Mean and standard errors of fertility of quails reared at different numbers of birds per cage and their interactions.

\begin{tabular}{|c|c|c|}
\hline Birds per cage & Meat-type quails & Egg-type quails \\
\hline 3 & $99.47 \pm 0.53 \mathrm{Aa}$ & $96.94 \pm 1.39 \mathrm{Aa}$ \\
\hline 6 & $96.38 \pm 0.94 \mathrm{Ab}$ & $99.79 \pm 0.21 \mathrm{Aa}$ \\
\hline 9 & $98.20 \pm 0.66 \mathrm{Aa}$ & $98.00 \pm 0.31 \mathrm{Aa}$ \\
\hline
\end{tabular}

$a-b-M e a n s \pm S E$ within a column (capital letter) and line (small letter) that do not share a common superscript are significantly different $(p<$ $0.05)$.
Quail fertility and hatchability were higher the values reported in literature for the investigated age in all treatments. Egg-type quails with 18-21 weeks presented $88 \%$ fertility and $75 \%$ hatchability when the ratio of females per male was two to three (M urakami $\&$ A riki, 1998). Hatchability was not influenced by quail type or the number of birds per cage.

The presence of three males in the cage, which could increase mating chances, was not associated with a higher number of spermatozoa in the female genital tract, as suggested by the number of IPVL holes (Figure 1), which result from acrossomal reaction and the consequent digestion of the perivitelline membrane (W ishart \& Staines, 1999; Bakst \& How arth, 1977; Hazary et al., 2000). The number of IPVL holes in vivo is highly correlated to fertility (Bramwell et al., 1995), because it is associated with the number of spermatozoa that reach an egg in the infundibulum at fecundation (W ishart, 1987).

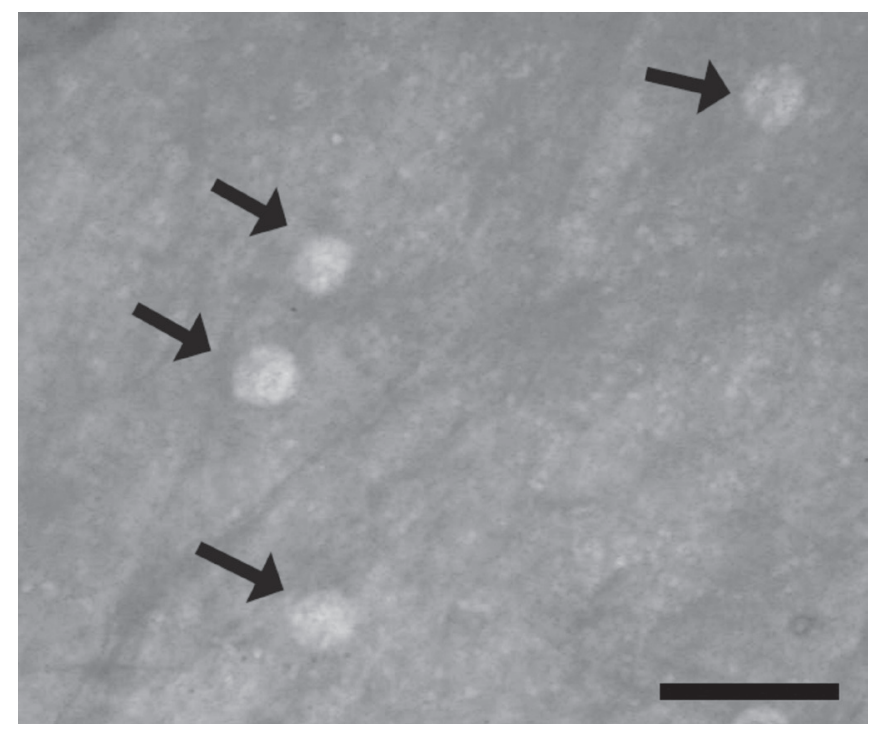

Figure 1 - IPVL holes (arrows) in the vitelline membrane of a fertile quail egg over germinal disc area. PAS, Scale bar: $100 \mu \mathrm{m}$.

In chickens, 0.3 IPVL holes per $\mathrm{mm}^{2}$ in the membrane over the germinal disc indicate $98 \%$ probability of egg fertilization (Wishart \& Staines, 1999). The analyzed meat-type quail eggs presented 2.89 and 0.84 IPVL holes $/ \mathrm{mm}^{2}$ over the germinal disc and opposite to it, respectively, whereas in egg-type quails, the number of holes was 2.15 and 0.63 hydrolysis holes $/ \mathrm{mm}^{2}$ in the same sites. Rabbani et al. (2006) analyzed different regions of the perivitelline membrane of quail eggs under light microscopy and found 3.57 hydrolysis holes $/ \mathrm{mm}^{2}$, with no differences as to membrane region, i.e., neither over the germinal disc, nor the 
opposing pole. The present study, however, indicated differences between these regions. No difference ( $p>0.05$ ) was observed among group size for these parameters, which ranged from 0.3 to 10.3 holes $/ \mathrm{mm}^{2}$ in the perivitelline membrane over the germinal disc (Figure 2).

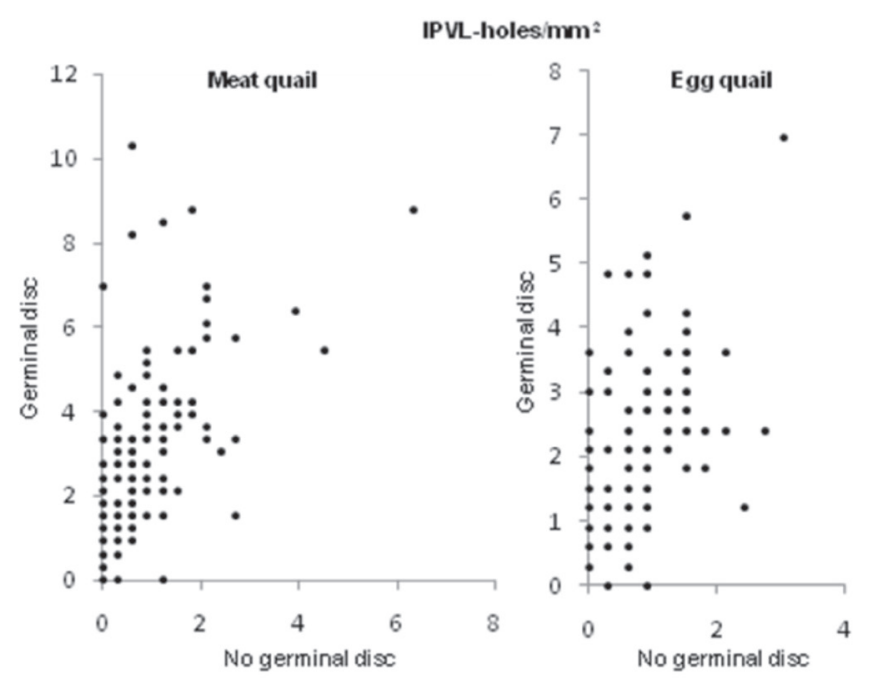

Figure 2 - Distribution of IPVL holes on the vitelline membrane per square millimeter over the germinal disc and the opposite pole in eggs of meat-type ( $n=137$ ) and egg-type quails $(n=130)$.

The number of IPVL holes is directly related to the number of viable spermatozoa in the female reproductive tract (Wishart, 1987; Brillard \& Bakst, 1990; Bakst, 1993; Brillard, 1993; Bramwell et al., 1995) and to the number of spermatozoa that reach the oocyte in the infundibulum of female birds studied so far (Wishart \& Staines, 1999). The same is expected to occur in quails. Consequently, this number also reflects the amount of sperm that each female receives during mating. As a result, it is possible that the number of sperm that reached and perforated the perivitelline membrane was not influenced by the number of males in the same cage, suggesting that the observed fertility rate of more than $98 \%$ was maintained when the ratio of one male to two females was kept (Table 2-3), even in cages with nine birds, where three males competed to mate with six females.

The number of IPVL was not influenced by the number of birds per cage, which suggests that the number of males inside the cage did not modify the pool of spermatozoa inside female's oviduct. These data suggest that six females exposed to three males received the same number of spermatozoa as four females exposed to two males and tw o females exposed to one male. The reproductive behavior of quails was not analyzed in this study. New studies may elucidate if reproductive hierarchy affects the reproductive performance in larger quail groups housed at larger numbers of birds per cage.

Despite differences in production parameters, the observed averages were typical of meat- and egg-type quails, suggesting that large breeder groups can be housed with no adverse effects on performance. In conclusion, according to the results obtained in the present study, a ratio of two females per male in cages with three, six, and nine birds/cage is recommended, as no deleterious effects on quail reproduction were observed.

\section{REFERENCES}

Adkins-Regan E. Predictors of fertilization in the Japanese quail, Coturnix japonica. Animal Behavior 1995; 50:1405-1415.

Albino LFT, Barreto SLT. Criação de codornas para produção de ovos e carne. Viçosa: A prenda Fácil; 2003. 268p.

Araujo MS, Barreto SLT, Donzele JL, Oliveira RFM, Umigi RT, Oliveira WP, Balbino EM, Assis AP, Maia GVC. Níveis de cromo orgânico na dieta de codornas japonesas mantidas em estresse por calor na fase de postura. Revista Brasileira de Zootecnia 2007; 36(3):584-588.

Bacon WL, Nestor KE. Reproductive preponse to intermittent light regimens in Coturnix coturnix japonica. Poultry Science 1975; 54:1918-1926.

Bakst M, Howarth B. Hydrolysis of the hen's perivitelline layer by cock sperm in vitro. Biology of Reproduction 1977; 17:370-379.

Bakst MR. Oviducal sperm storage in poultry: a Review . Reproduction Fertility and Development 1993; 5:595-9.

Barreto SLT, Araujo MS, Umigi RT, M oura WCO, Costa CHR, Souza MF. Níveis de sódio em dietas para codorna japonesa em pico de postura. Revista Brasileira de Zootecnia 2007b; 36(5):1559-1565.

Barreto SLT, Quirino BJS, Brito CO, Umigi RT, Araujo MS, Rocha TC, Pereira CG. Efeitos de níveis nutricionais de energia sobre 0 desempenho e a qualidade de ovos de codornas européias na fase inicial de postura. Revista Brasileira de Zootecnia 2007a; 36(1):8693.

Bramwell RK, Marks HL, Howarth Jr B. Quantitative determination of spermatozoa penetration of the perivitelline layer of the hen's ovum as assessed on ovoposited eggs. Poultry Science 1995; 74:1875-1883.

Bramwell RK, McDaniel CD. Influence of spermatozoa numbers and insemination frequency on fertility in dwarf broiler breeder hens. Poultry Science 1986; 65:2330-34.

Brillard JP, Bakst MR. Quantification of spermatozoa in the sperm- 
storage tubules of turkey hens and its relation to sperm numbers in the perivitelline layer eggs. Biology of Reproduction 1990; 43:27175.

Brillard JP. Sperm storage and transport following natural mating and artificial insemination. Poultry Science 1993; 77:923-28.

Clulow J, Jones RC. Production, transport, maturation, storage and survival of spermatozoa in the male Japanese quail, Coturnix coturnix. Journal of Reproduction and Fertility 1982; 64:259-266.

Faitore ABG, Pavan AC, Mori C, Batista LS, Oliveira RP, Garcia EA, Pizzolante CC, Mendes AA, Sherer MR. Economic traits and performance of italian quails reared at different cage stocking densities. Revista Brasileira de Ciências Avícolas 2005; 7(1):19-22.

Garcia J, Murakami AE, Martins EM, Furlan AC. Exigências nutricionais de cálcio e fósforo para codornas japonesas (Coturnix coturnix japonica) em postura. Acta Scientiarum. Animal Science 2000; 22(3):733-739.

Hassan SM, Mady ME, Cartwright AL, Sabri HM, Mobarak MS. Effect of feeding time on the reproductive performance of Japanese Quail (Coturnix coturnix japonica). Poultry Science 2003; 82:1188-1192.

Hazary RC, Staines HJ, Wishart GJ. Assessing the efficiency of mating in broiler breeder flocks by enumerating the spermatozoa which penetrate the inner perivitelline layer over the germinal disc. British Poultry Science 2000; 41:395-400.

Kadam M M, M andal AB, Elangovan AV, Kaur S. Response of laying Japanese quail to dietary calcium levels at two levels of energy. Journal of Poultry Science 2006; 43(4):351-356.

Kobayashi S, Hamaguchi H, Sakai S, Okamoto S, Matsuo T. Influence of intensity of lighting on egg production rate and ovoposition rhythm in Japanese quail under 14 L:10 D light and dark cycle. Japanese Poultry Science 1994; 31:130-136.

Kosin II. The accuracy of the macroscopic method in identifying unincubated germ discs. Poultry Science 1945; 24:281-295.

Lopes IRV, Fuentes M FF, Freitas ER, Soares M B, Ribeiro OS. Efeito da densidade de alojamento e do nível de energia metabolizável da ração sobre o desempenho zootécnico e características dos ovos de codornas japonesas. Revista Ciência Agronômica 2006; 37(3):369-375.

Mori C, Garcia EA, Pavan AC, Piccinin A, Scherer MR, Pizzolante CC. Desempenho e qualidade dos ovos de codorna de quatro grupos genéticos. Revista Brasileira de Zootecnia 2005; 34(3):864869.

Moura GS, Barreto SLT, Donzele JL, Hosoda LR, Pena GM, Angelini MS. Dietas de diferentes densidades energéticas mantendo constante a relação energia metabolizável:nutrientes para codornas japonesas em postura. Revista Brasileira de Zootecnia 2008; 37(9):1628-1633.

Murakami AE, Ariki J. Produção de codornas japonesas. Jaboticabal: FUNEP, 1998. 79p.
Murakami AE, Fernandes JIM, Sakamoto MI, Souza LMG, Furlan AC. Efeito da suplementação enzimática no desempenho e qualidade dos ovos de poedeiras comerciais. Acta Scientiarum. Animal Science 2007; 29(2):165-172.

Murakami AE, Sakamoto MI, Souza LMG, Franco JRG, Mituo MAO. Determinação do melhor nível de sal comum para codornas japonesas em postura. Revista Brasileira de Zootecnia 2006; 35(6):2333-2337.

Murakami AE, Souza LMG, Sakamoto MI, Fernandes JIM. Using processed feeds for laying quails (Coturnix coturnix japonica). Revista Brasileira de Ciência Avícola 2008; 10(4):205-208.

Narahari D, Mujeer KA, Thangavel A, Ramamurthy $N$, Viswanathan S, Mohan B, Muruganandan B, Sundararasu V. Traits influencing the hatching performance of japanese quail eggs. British Poultry Science 1988; 29:101-112.

National Reserch Council - NRC. Nutrient requirements of poultry. 9th ed Washington: National Academy of Sciences; 1994.155p.

Oliveira CAF, Ogido R, Ledoux DR, Rottinghaus GE, Corrêa B, Reis $T A$, Gonçalez $E$. The quality of eggs from Japanese quail, Coturnix japonica, fed rations containing aflatoxin B1 and fumonisin B1. Journal of Poulry Science 2007; 44(1):29-33.

Petek M, Baspinar H, Ogan M. Effects of egg weight and length of storage on hatchability and subsequent growth performance of quail. South African Journal of Animal Science 2003; 33(4):242-247.

Rabbani MG, Sasanami T, Mori M, Yoshizaki N. Characterization of the sperm-associated body and its role in the fertilization of the chicken Gallus domesticus. Development, Growth and Differentiation 2007; 49:39-48.

Reddish JM, Kirby JD, Anthony NB. Analysis of poultry fertility data. 3. Analysis of the duration of fertility in naturally mating Japanese quail. Poultry Science 1996; 75:135-9.

Ribeiro M LG, Silva JHV, Dantas M O, Costa FGP, Oliveira SF, Filho J, Silva EL. Exigências nutricionais de lisina para codornas durante a fase de postura, em função do nível de proteína da ração. Revista Brasileira de Zootecnia 2003; 32(1):156-161.

Rostagno HS, Albino LFT, Donzele JL, Gomes PC, Oliveira RF, Lopes DC, Ferreira AS, Barreto SLT. Tabelas brasileiras para aves e suínos. Composição de alimentos e exigências nutricionais. Viçosa: Universidade Federal de Viçosa; 2000.

SAS Institute. User's guide 8.0. SAS Institute. Cary, NC; 2000.

Sittmann K, Abplanalp $H$. Duration and recovery of fertility in Japanese quail (Coturnix coturnix japonica). British Poultry Science $1965 ; 6: 245-250$.

Wishart GJ, Staines HJ. Measuring sperm:egg interaction to assess breeding efficiency in chickens and turkeys. Poultry Science 1999; 78:428-436.

Wishart GJ. Regulation of the length of the fertile period in the domestic fowl by numbers of oviducal spermatozoa. Journal of Reproduction and Fertility 1987; 80:493-98. 